\title{
Distribution of Extracellular Matrix Proteins in Primary Human Brain Tumours: An Immunohistochemical Analysis
}

\author{
James T. Rutka, Craig A. Myatt, Jane R. Giblin, Richard L. Davis \\ and Mark L. Rosenblum
}

\begin{abstract}
Using immunohistochemical techniques, we localized several glycoproteins of the extracellular matrix in paraffin-embedded sections of 4 normal brain and 38 primary intracranial tumour specimens. All specimens were positively immunostained to various degrees by monoclonal antibodies to type IV collagen and procollagen III and by antisera to laminin and fibronectin. Staining was consistently most intense at sites of contact between neuroepithelial and mesenchymal or leptomeningeal elements; there was no demonstrable staining within or between neuroepithelial elements in the neuropil. Tumour cells from meningiomas and from the sarcomatous portion of a gliosarcoma were positively immunostained for fibronectin and laminin. The integrity of the glial limitans externa was demonstrated by the positive linear reaction product produced by immunostains for type IV collagen and laminin, even in the most malignant gliomas. The deposition of extracellular matrix glycoproteins at the glial-mesenchymal interface observed in this study of primary human brain tumours is a manifestation of one of the interactions between tumour and stromal cells in the central nervous system. A loss of coordination and an alteration in the interactions between epithelial cells and stromal cells across extracellular matrices such as basement membranes are thought to be fundamental steps in the development and progression of cancer. Further characterization studies focusing on other markers of the extracellular matrix are needed to elucidate completely the function of this structure in the central nervous system.
\end{abstract}

RÉSUMÉ: Répartition des protéines de la matrice extracellulaire dans les tumeurs primitives du cerveau chez l'être humain: une analyse immunohistochimique Nous avons localisé, au moyen de techniques immunohistochimiques, plusieurs glycoprotéines de la matrice extracellulaire dans des sections paraffinées de tissu provenant de 4 cerveaux normaux et de 38 tumeurs intracrâniennes primitives. Tous les spécimens présentaient une réaction immunologique positive, à différents degrés, à la coloration par anticorps monoclonaux dirigés contre le collagène de type IV et le pro-collagène III et par antisérum dirigé contre la laminine et la fibronectine. La coloration était toujours plus intense aux sites de contact entre les élements neuro-épithéliaux du mésenchyme ou des leptoméninges; par contre, il était impossible de mettre en évidence la coloration à l'intérieur ou entre les éléments neuro-épithéliaux dans le neuropile. Les cellules tumorales provenant de méningiomes et de la portion sarcomateuse d'un gliome présentaient une réaction immunohistochimique positive pour la fibronectine et la laminine. Même dans les gliomes les plus malins. l'intégrité de la membrane limitante externe était mise en évidence sous forme d'une réaction positive linéaire produite lors de la coloration par immunoréaction dirigée contre le collagène de type IV et la laminine. Le dépôt de glycoprotéines de la matrice extracellulaire, à l'interface glie-mésenchyme, observé au cours de la présente étude de tumeurs primitives du cerveau humain est une manifestation de l'une des interactions entre cellules tumorales et cellules du stroma dans le système nerveux central. Une perte de la coordination et une altération de l'interaction entre les cellules épithéliales et les cellules du stroma sont considérées comme étant des étapes fondamentales dans le développement et la progression du cancer. Il est nécessaire de procéder à des études plus poussées, portant sur d'autres marqueurs de la matrice extracellulaire, dans le but d'expliquer la fonction de cette structure dans le système nerveux central.

Can. J. Neurol. Sci. 1987: 14:25-30

From The Brain Tumor Research Center. Department of Neurological Surgery and the Department of Pathology (Neuropathology). School of Medicine, University of California, San Francisco, California

Dr. Rutka is a Fellow of the Medical Research Council of Canada

Received April 17, 1986. Accepted in final form September 8, 1986

Reprint requests to: James T. Rutka. M.D. Department of Neurological Surgery. c/o The Editorial Office. 1360 Ninth Avenue. Suite 210. San Francisco. California 94122 
The extracellular matrix (ECM) may be defined as the naturally occurring extracellular substrate upon which cells migrate, proliferate, and differentiate in vivo. ${ }^{1.2}$ The ECM functions as a biological adhesive that maintains the normal cytoarchitecture of different tissues and defines the key spatial relationships among dissimilar cell types. ${ }^{3}$ Outside the central nervous system (CNS), the ECM plays a fundamental role in modulating tumour cell invasion and metastasis. ${ }^{4.5}$ Although much has been learned about the biochemical composition and structure of the ECM in other organs, little is known of its structure and function in the CNS. ${ }^{6.7}$ We undertook this study to characterize the distribution of laminin, collagen type IV, fibronectin, and procollagen type III in primary human brain tumours and to determine which cells may be involved in the production of these ECM proteins.

\section{Materials and MethodS}

\section{Monoclonal Antibodies and Antisera}

A panel of monoclonal antibodies and antisera was used to localize ECM proteins in the tissue sections. Lyophilized antibody against laminin and fibronectin, raised in rabbits, was a gift from Dr. H. Kleinman (National Institute of Dental Research, NIH, Bethesda, MD). Monoclonal antibodies to procollagen type III and collagen type IV were donated by $\mathrm{Dr}$. N. SundarRaj (University of Pittsburg, Pennsylvania). Brain tumours of glial anlage were immunohistochemically identified by a rabbit anti-human antiserum to glial fibrillary acidic protein (GFAP), which was a gift from Dr. L. Eng (Stanford, CA). Cerebrovascular endothelial cells were stained by a rabbit antihuman Factor-VIII-related antiserum (Dako, Westbury, NY). The specificity of all antisera and monoclonal antibodies used in this study have been reported in detail elsewhere. ${ }^{8}$

\section{Tumour Selection and Tissue Preparation}

Thiry-eight tumours and 4 normal brain specimens were selected for study (Table 1). The pathological diagnosis of each tumour was confirmed by one of us (RLD). The gliomas were classified using criteria established at the University of California, San Francisco (UCSF). ${ }^{9}$ A glioblastoma multiforme is a highly cellular glial neoplasm with nuclear and cytoplasmic pleomorphism and vascular endothelial proliferation. A highly anaplastic astrocytoma is a moderately to highly cellular glial

Table 1: CNS tumors and normal brain specimens examined for extracellular matrix protein expression.

\begin{tabular}{lc}
\hline \hline Hlstopathological Diagnosis & No. \\
\hline Glioblastoma multiforme & 10 \\
Highly anaplastic astrocytoma & 6 \\
Moderately anaplastic astrocytoma & 3 \\
Gemistocytic astrocytoma & 2 \\
Gliosarcoma & 3 \\
Oligodendroglioma & 2 \\
Ependymoma & 2 \\
Medulloblastoma & 2 \\
Meningioma & 6 \\
malignant & 2 \\
Normal human brain & adult \\
fetal & 2 \\
$\quad$ Total & 2 \\
&
\end{tabular}

neoplasm with at least two of the following characteristics: a high nuclear:cytoplasmic ratio, coarse nuclear chromatin, mitotic activity, and nuclear or cytoplasmic pleomorphism. A moderately anaplastic astrocytoma is a mildly to moderately cellular glial neoplasm with enlarged nuclei and a relatively uniform cytoplasm. GFAP was used as a marker to identify tumours of glial origin.

For comparison with the tumour specimens, samples of normal human brain were obtained from adult patients undergoing routine craniotomies for trauma or intractable seizures and from normal fetuses electively aborted at 12-20 weeks'gestation. Permission to obtain the fetal brain specimens was granted by the Human Research Committee of the University of California, San Francisco.

All specimens were fixed for 24 hours at $0-4^{\circ} \mathrm{C}$ in Carnoy's solution ${ }^{10}$ or in $10 \%$ neutral buffered formalin. ${ }^{11}$ The paraffinembedded tissue blocks were cut into sections $5.5 \mu \mathrm{m}$ thick, mounted on glycerin-coated glass slides, deparaffinized, and rehydrated. Sections fixed in Carnoy's solution were pretreated with $0.05 \%$ collagenase (Sigma type $\mathrm{I}, \mathrm{C} 0130$ ) in $0.05 \% \mathrm{CaCl}_{2}$, pH7.4 $4^{10}$ and those fixed in formalin were pretreated with $0.4 \%$ pepsin (Sigma) in $0.01 \mathrm{~N} \mathrm{HCl}$ for 45 minutes at $37^{\circ} \mathrm{C}$ before immunostaining. ${ }^{\prime \prime}$ Tissue sections immunostained for GFAP were not pretreated with proteolytic enzymes.

\section{Immunohistochemical Staining}

The intracytoplasmic and ECM proteins were immunostained with the peroxidase-antiperoxidase (PAP) technique of Sternberger. ${ }^{12}$ For the primary antibodies raised in rabbits, PAP kit K548 (Dako) was used; for mouse monoclonal antibodies, PAP monoclonal kit K660 (Dako) was used. Primary antibodies (anti-GFAP, -fibronectin, -Factor-VIII-related antigen, and -laminin diluted 1:200; anti-procollagen type III and -type IV collagen diluted 1:100) were allowed to incubate overnight at $4^{\circ} \mathrm{C}$. The slides were carefully rinsed in phosphate-buffered saline after each step. The sections were then counterstained with hematoxylin and mounted with glycerol gelatin (Sigma). Immunostaining of ECM proteins in blood vessels in tumour sections served as an internal positive control. In control sections, the primary antibody was replaced with either nonimmune rabbit serum (Dako) or ascites fluid (Cappel) at the same dilution as the primary antibody.

\section{Results}

The difference in fixation technique did not affect the intensity of staining. However, preincubation of the specimens with the appropriate proteolytic enzyme was necessary to localize and enhance the various ECM reaction products. All 42 specimens were positively immunostained to various degrees by all of the antisera and antibodies to the ECM proteins. Staining was most consistent for laminin, type IV collagen, and fibronectin and was most variable for procollagen type III. FactorVIII/vWF-related antigen distinctly stained endothelial cells in all blood vessels; the subendothelial basement membrane and the perivascular regions stained less intensely.

\section{Normal Brain}

In the adult human brain specimens, laminin and type IV collagen were identically distributed in the basal lamina of cerebral parenchymal and leptomeningeal blood vessels (Figure 
1) and in the glial limitans externa. The procollagen type III reaction product was noted chiefly in the fibromuscular compartment of the larger arterioles and arteries of the leptomeninges and brain. Corpora amylacea in one specimen were positively identified by immunostains for fibronectin. In the fetal brain specimens, the distribution of all ECM macromolecules was similar to that of adult brain. In addition, the vascular and epithelial basement membranes of the choroid plexus stained positively and perivascular immunostaining for the various glycoproteins was observed even in the paraventricular germinal layer (Figure 2).

\section{Glioblastoma Multiforme}

The most striking aspect of all 10 glioblastomas was the intratumoral vascularity, which was identified by antisera or antibodies to all ECM macromolecules (Figure 3). Staining was particularly intense in thick-walled, hyperplastic blood vessels and in glomeruloid vascular formations. There was only occasional fragmentation of the endothelial basement membrane (Figure 4). The glial limitans externa was also identified in all specimens and was similarly intact. Laminin and collagen type IV were similarly distributed along the endothelial basal laminae, but some less intense staining was seen beyond the basement membrane. Fibronectin was identified throughout all layers of blood vessels; some thick-walled vessels had a laminated appearance (Figure 5). Procollagen type III was also immunolocalized to all layers of proliferated vessels. Immunostaining showed no evidence of ECM glycoproteins between glial tumour cells.

\section{Gliosarcoma}

Gliomatous regions of the three gliosarcomas were positively identified by immunostains for GFAP. Giant cells were negative for GFAP in two cases and positive in one. Sarcomatous regions were positively identified by immunostains for fibronectin, laminin, type IV collagen, and procollagen type III in two tumours (Figure 6). Granular, intracytoplasmic staining for laminin and fibronectin was present in the cytoplasm of some cells in the sarcomatous portion of one tumour.

\section{Other Gliomas}

The staining pattern for all ECM molecules in highly anaplastic gliomas was similar to that seen in glioblastomas multiforme. Vascular mesenchymal immunostaining was not as prominent. Both the glial limitans externa and the subendothelial basement membranes were intact. A moderately anaplastic astrocytoma was found to have a narrow, slit-like Virchow-Robin space that contained a moderately large arteriole with a lymphocytic infiltrate (Figure 7). None of the gliomas, including the ependymomas and the oligodendrogliomas, stained positively for any of the ECM proteins except in perivascular regions.

\section{Medulloblastoma}

In both medulloblastomas, ECM proteins were found in a perivascular distribution. In one tumour in which a desmoplastic response had occurred, strands of fibrous connective tissue were positively identified by antisera or antibodies to all of the ECM proteins.

\section{Meningioma}

All ECM proteins were positively identified by immunostaining in all eight meningiomas. None of these tumours stained positively for GFAP. The intrinsic vascularity of the meningiomas was extremely well delineated by immunostains for the ECM proteins. In addition, intracytoplasmic staining of laminin and fibronectin was seen in one malignant and two transitional meningiomas (Figure 8). Intercellular spaces in whorl formations and psammoma bodies were positively identified by antisera to fibronectin in a meningotheliomatous meningioma.

\section{Discussion}

The extracellular space of the CNS has yet to be completely characterized. Whereas the parenchyma of the CNS appears to be filled with a relatively amorphous matrix that is largely free of collagens and other fibrous proteins, ${ }^{6.7 .13}$ a well-defined ECM exists in the form of a true basement membrane around all cerebral blood vessels and at the glial limitans externa. ${ }^{7}$ As a delimiting basement membrane, the glial limitans externa invests the entire cortical surface of the brain and separates astrocytic foot processes from pia-arachnoid cells. Thus, it forms an interface between cellular CNS elements derived embryologically from neuroepithelium and leptomeningeal elements pre-

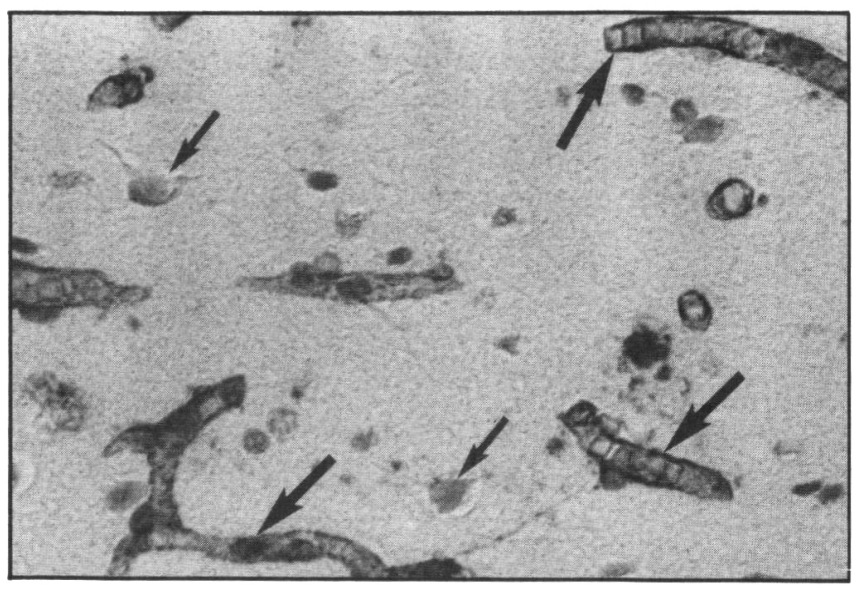

Figure I - Immunolocalization of type IV collagen in normal adult cerebral cortex. The thin-walled subendothelial basal laminae of the cortical capillaries are positively stained (large arrows). Neurons (small arrows) and intervening neuropil are unstained. Light microscopy, $x 200$.

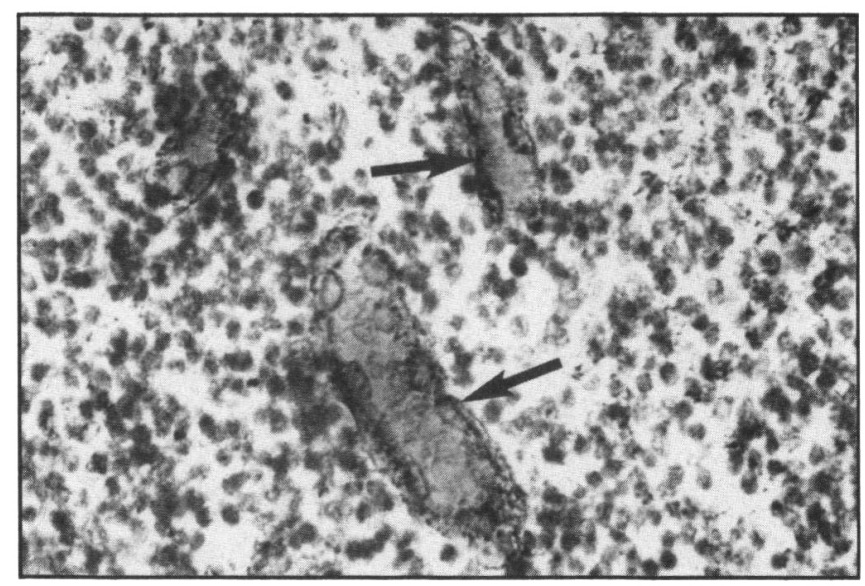

Figure 2 - Paraventricular germinal layer of human fetal brain, gestational age 18 weeks, stained for fibronectin. This densely cellular region demonstrates diffuse fibronectin positivity in all layers of the blood vessel walls (arrows). Light microscopy, $x 200$. 


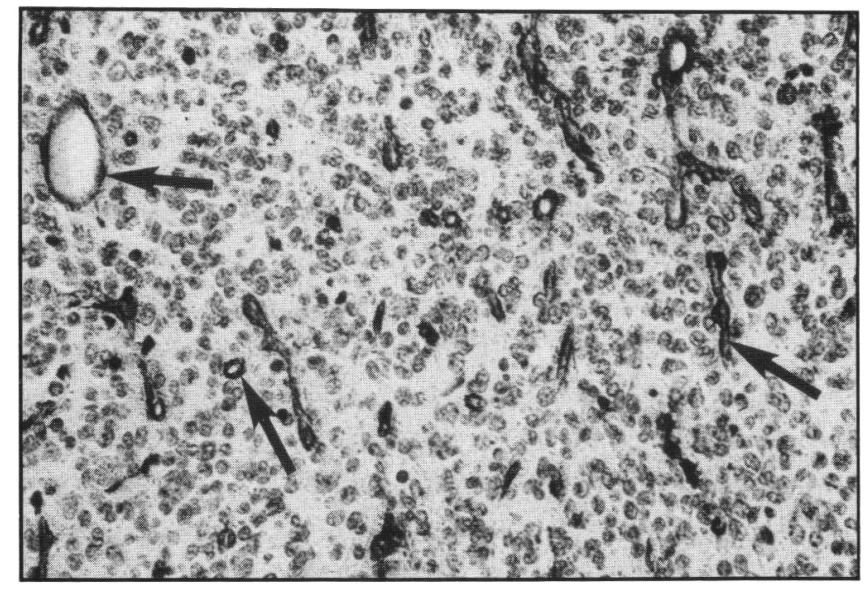

Figure 3-Immunostain for laminin clearly delineates the vascularity of a glioblastoma multiforme. The endothelial basement membrane in all large and small vessels is continuous and intact (arrows). Tumour cells are not stained. Light microscopy, $x 75$

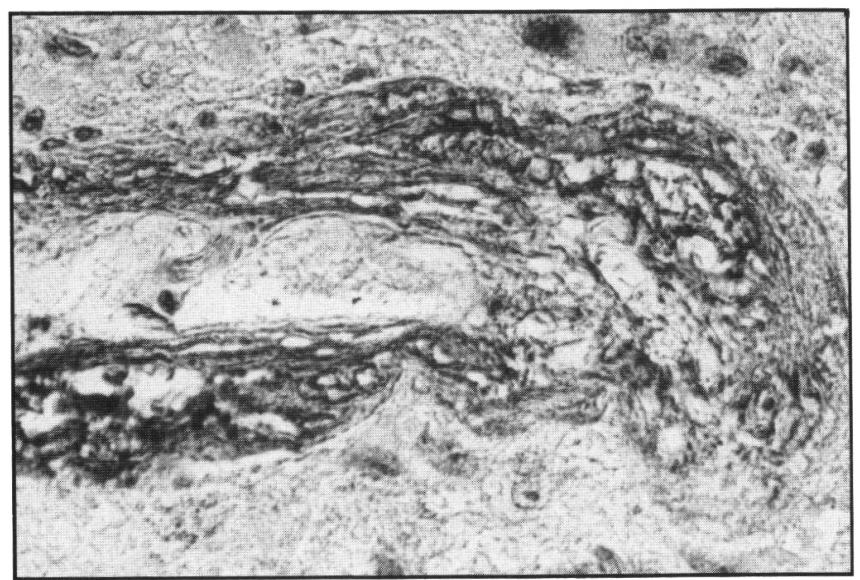

Figure 5 - Immunostain for fibronectin in a glioblastoma. The entire thickness of a large, tangentially sectioned blood vessel is stained positively and is composed of several laminae. Light microscopy, $x 200$

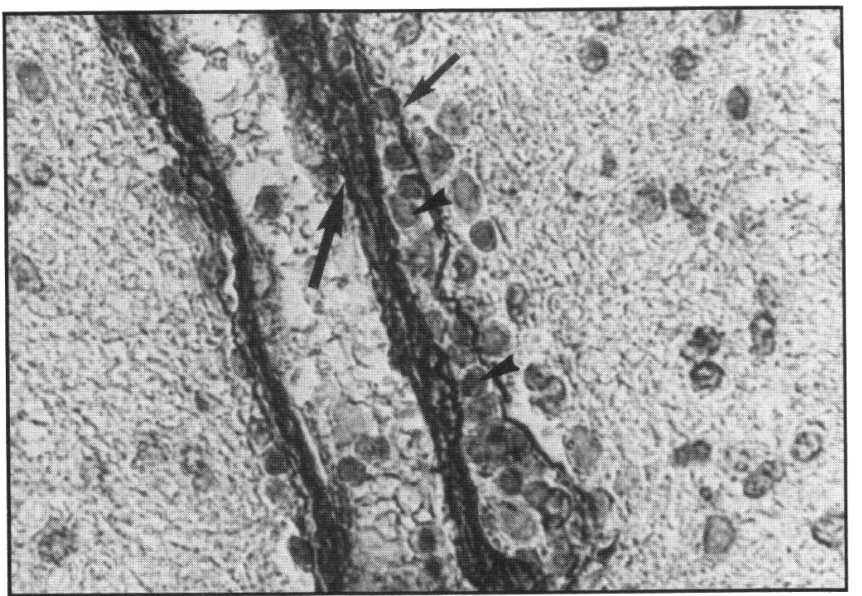

Figure 7 - Immunostain for laminin in a moderately anaplastic astrocvtoma identifies the subendothelial basement membrane of a longitudinally sectioned blood vessel (large arrow) and the glial limitans externa (small arrow). The glial limitans externa is intact. The Virchow-Robin space contains several lymphocyles (arrowheads). The tumour cells and intratumoral regions are unstained. Light microscopv, $x 200$

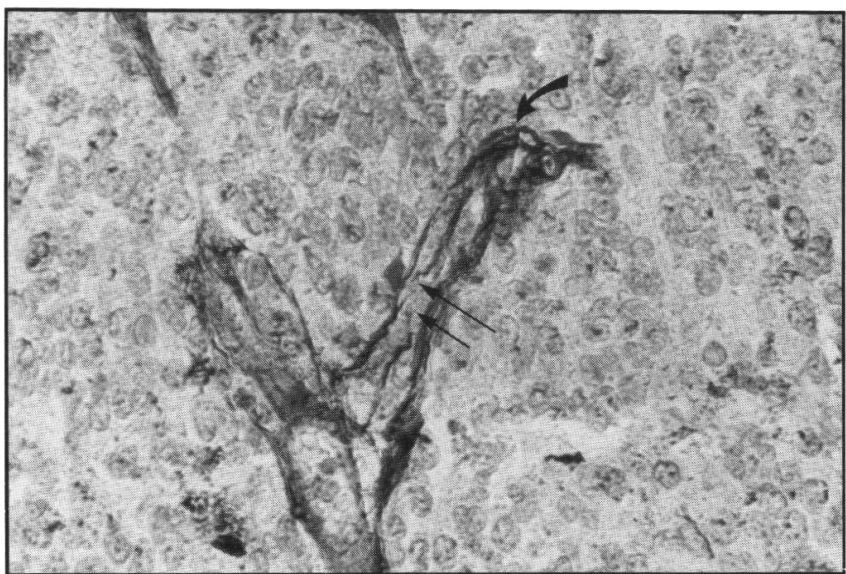

Figure 4 - Immunostain for laminin in a glioblastoma multiforme identifies a thick-walled hyperplastic blood vessel (curved arrow) and a fragmented endothelial basement membrane (straight arrow) of a thin-walled blood vessel cut longitudinally, Light microscopy, $x 500$

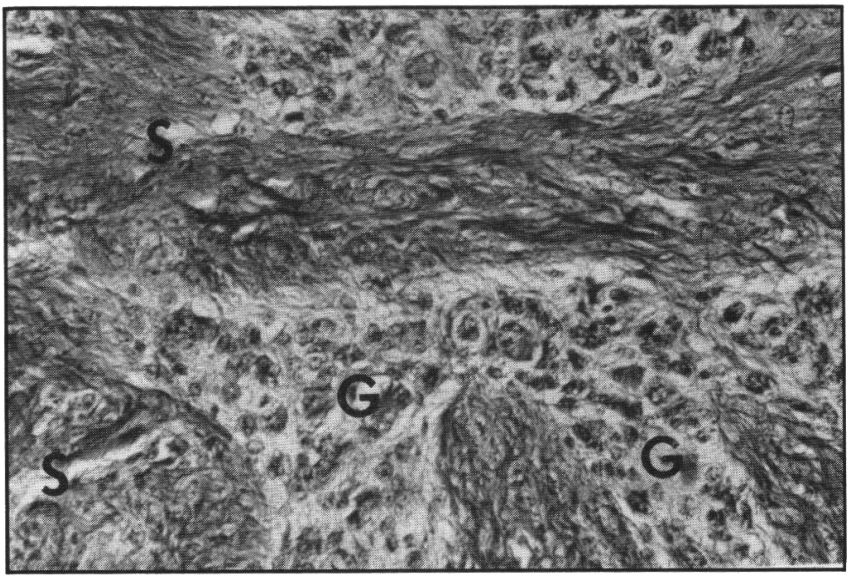

Figure 6 - Immunostain for procollagen III in a gliosarcoma show's that sarcomatous regions $(S)$ are separated from gliomatous regions $(G)$ and stain positively for procollagen III. Light microscopv. $x 75$.

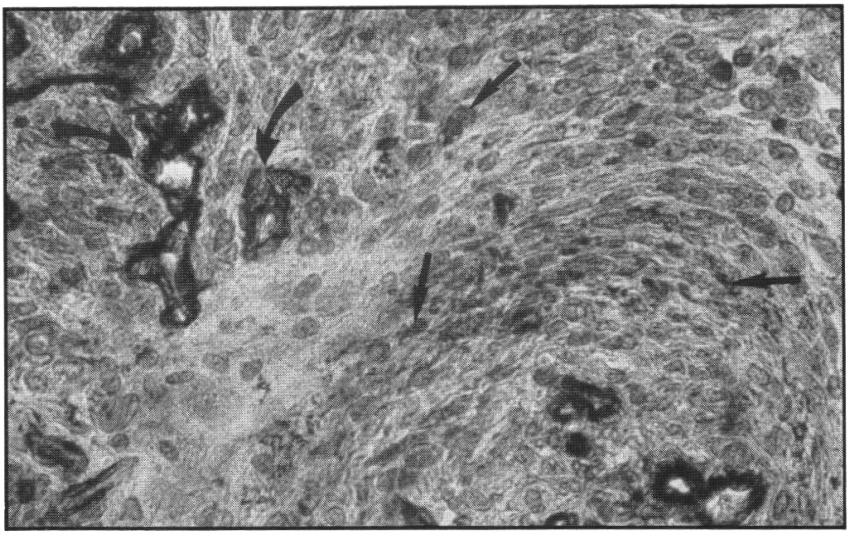

Figure 8-Meningiotheliomatous meningioma immumostained for laminin. The subendotheilal basement membrane of the blood vessels (curved arrows) and the cytoplasm of the meningioma cells are positively identified in a whorl formation (straight arrows). Light microscopv, $\times 200$. 
sumably derived from the neural crest. In other tissues outside the CNS, a loss of coordination and an alteration in the interactions between mesenchymal cells and epithelial cells across a basement membrane are thought to be fundamental steps in the development and progression of cancer. ${ }^{14}$

In most tissues, the ECM is composed of various types of collagen, noncollagenous glycoproteins such as laminin and fibronectin, glycosaminoglycans, and proteoglycans. ${ }^{15-18}$ Basement membranes are continuous ECMs consisting of type IV collagen, laminin, fibronectin, entactin, and heparan sulfate proteoglycan. ${ }^{16}$ Immunohistochemical studies of normal and pathological human CNS specimens have shown that ECM proteins are predominantly deposited at the junction between glial and mesenchymal elements. ${ }^{10,11,12.13 .19-23}$

Conventional histological stains such as reticulin and alcian blue do not accurately define the biochemical composition of the ECM because they recognize only large aggregate mixtures of ECM components. With monoclonal antibodies and antisera that identify individual ECM proteins, however, biochemically complex structures such as the glial limitans externa can be completely characterized. ${ }^{24}$ Another important advance in the immunohistochemical analysis of the ECM was the discovery that proteolytic enzymes can restore the antigenicity of formalinfixed, paraffin-embedded tissues. ${ }^{10.25 .26}$ As a fixative, formalin links proteins by intermolecular bonds that render antigen binding sites temporarily inaccessible. ${ }^{27}$ Incubation of tissue sections with weak solutions of pepsin, trypsin, or pronase before immunostaining enhances staining of the $\mathrm{ECM}^{10.25}$ without affecting cell preservation or increasing background staining. Incubation with proteolytic enzymes has also consistently enhanced the immunostaining of CNS specimens fixed in Carnoy's solution, even though it is not a cross-linking fixative. ${ }^{10,23}$

Laminin has been immunolocalized to hyperplastic blood vessels and glomerular vascular formations in gliomas, ${ }^{10,20}$ in the cytoplasm of the sarcomatous elements of some gliosarcomas, ${ }^{23}$ and in the vasculature and fibrillary extracellular spaces of some meningiomas. ${ }^{1,20}$ Immunostaining for laminin has shown that the glial limitans externa and the subendothelial basal laminae of blood vessels are almost always intact, even in the most anaplastic gliomas. ${ }^{1.20}$ In addition to this pattern of laminin immunoreactivity, in our study we were able to demonstrate a laminin reaction product in the cytoplasm of meningioma cells. The finding of laminin in the sarcomatous portion of gliosarcomas in vivo and in vitro ${ }^{28}$ suggests that regardless of their histological origin, sarcoma cells synthesize rather than phagocytose laminin, as was previously hypothesized. ${ }^{23}$

In the CNS, fibronectin has been immunolocalized to the gliomesenchymal junction in vivo..$^{10.21 .22 .29 .30}$ In addition to staining of all layers of both normal and tumour-associated blood vessels, the glial limitans externa, the leptomeninges, and meningioma cells in whorl formations, we demonstrated intense fibronectin immunoreactivity at the border between gliomatous and sarcomatous elements in a gliosarcoma and in the copora amylacea of a normal brain specimen.

The interstitial collagens, types I and III, have been immunolocalized to the leptomeninges, the fibromuscular coats of large cerebral blood vessels, and the glial limitans externa. ${ }^{13.19}$ Because of the ubiquity of the interstitial collagens in various tissues throughout the body, types I and III collagens tend to be weak immunogens. ${ }^{31}$ We therefore used a monoclonal antibody to procollagen III, the aminopropeptide of type III collagen, to enhance the sensitivity of staining for type III collagen in the CNS. Procollagen III was found in blood vessel walls, in the leptomeninges, and in the sarcomatous element of the gliosarcoma.

Using an immunofluorescence analysis, Bellon et al ${ }^{19}$ localized type IV collagen to the subendothelial basement membrane of blood vessels in gliomas and meningiomas. The antibody to type IV collagen produced a linear staining pattern in capillaries and large vessels. Type IV collagen and laminin were localized to the same areas. Our results are similar to those of Bellon et al. ${ }^{19}$ In addition, we found that neuroepithelial derivatives (glia, neurons, glioma cells) never stained positively, even in the fetal brain specimens, and that the glial limitans externa identified by the monoclonal antibody to type IV collagen remained intact even in the most malignant gliomas.

The integrity of basal laminae in the CNS, even in large malignant tumours, is in some ways contrary to the currently accepted paradigm of malignant cell behaviour. Tumour invasiveness is a function of the ability of malignant tumour cells to transgress normal tissue barriers such as basement membranes. ${ }^{32.33}$ For example, at the transition from in situ to invasive carcinoma, local dissolution of the epithelial basement membrane can be observed microscopically and coincides with tumour cell invasion of the underlying stroma. ${ }^{33}$ Tumour cells that metastasize hematogenously must cross the endothelial basement membrane during entry into and egress from blood vessels. The success of malignant tumour cells in penetrating ECMs such as basement membranes, which are resilient mechanical barriers to invasion, depends in part on the ability of these cells to produce specific proteases. ${ }^{16,34}$ For poorly understood reasons, malignant gliomas rarely metastasize extracranially, ${ }^{35-37}$ In only $10-12 \%$ of cases does glioblastoma multiforme spread into cerebrospinal fluid pathways; in such cases, spread occurs as a result of ventricular or leptomeningeal involvement. ${ }^{38}$

In summary, the immunohistochemical data obtained in this study suggest that collagenous and noncollagenous glycoproteins of the ECM in the normal CNS are found predominantly at sites of contact between neuroepithelial and mesenchymal or leptomeningeal elements. Which subclass of cells in the CNS synthesizes and deposits the various ECM components in in vivo remains an unanswered question; however, there is evidence that, at least in vitro, both immature astrocytes and normal adult leptomeningeal cells can synthesize basement membrane proteins. ${ }^{27.39}$ In addition, we have demonstrated that the cytoplasm of certain meningioma cells is positively identified by antibodies to laminin and fibronectin, which strongly implies that these tumourcells produce laminin and fibronectin. Finally, we have confirmed that the integrity of the glial limitans externa is often preserved, even in the most malignant gliomas. Further studies that focus on the distribution of other major components of the ECM such as the glycosaminoglycans and proteoglycans will be of great value in determining the role of this structure in the CNS under normal and pathological conditions.

\section{ACKNOWLEDGEMENTS}

This study was supported in part by a grant from the Preuss Foundation and by grants CA-13525 and CA-31882 from the National Cancer Institute, National Institutes of Health. The authors thank Cindy Huff for typing the manuscript and Stephen Ordway for editorial assistance. 


\section{REFERENCES}

1. Gospodarowicz D, Greenburg G, Birdwell CR. Determination of cellular shape by the extracellular matrix and its correlation with the control of cellular growth. Cancer Res 1978; 38: 4155-4171.

2. Gospodarowicz D, Tauber JP. Growth factors and the extracellular matrix. Endocr Rev 1980; 1: 210-227.

3. Reid LM Fefferson DM. Cell culture studies using extracts of ECM to study growth and differentiation in mammalian cells. In Mather JP, ed. Mammalian Cell Culture. New York: Plenum, 1984: 239-280.

4. Terranova VP, Williams JE, Liotta LA et al. Modulation of metastatic activity of melanoma cells by laminin and fibronectin. Science 1985; 226: 982-985.

5. Terranova VP, Liotta LA, Russo RG et al. Role of laminin in the attachment of murine tumor cells. Cancer Res 1982;42: 2265-2269.

6. Bunge RP, Bunge MB. Interrelationships between Schwann cell function and extracellular matrix production. Trends in Neuroscience 1983; 3: 499-503.

7. Carbonetto $S$. The extracellular matrix of the nervous system. Trends in Neuroscience 1984; 7: 382-387.

8. Rutka JT, Giblin J, Dougherty DV et al. An ultrastructural and immunocytochemical analysis of leptomeningeal and meningioma cultures. J Neuropathol Exp Neurol 1986; 45: 285-303.

9. Liu HL, Davis RL, Vestnys $P$ et al. Correlation of survival and diagnosis in supratentorial malignant gliomas. J Neuro-Oncol 1984; 2: 268a (abstr).

10. Mauro A, Bertolotto A, Germano I et al. Collagenase in the immunohistochemical demonstration of laminin, fibronectin, and factor VIII/RAg in nervous tissue after fixation. Histochemistry 1984; 80: 157-163.

11. McComb RD, Bigner DD. Immunolocalization of laminin in neoplasms of the central and peripheral nervous sytem. J Neuropathol Exp Neurol 1985; 44: 242-253.

12. Sternberger LA, Hardy PH Jr, Cuculis JJ et al. The unlabeled antibody enzyme method of immunohistochemistry: Preparation and properties of soluble antigen-antibody complex (horseradish peroxidase-anti-horseradish peroxidase) and its use in identification of spirochetes. J Histochem Cytochem 1970; 18 315-333.

13. Shellswell GB, Restall DJ, Duance VC et al. Identification and differential distribution of collagen types in the central and peripheral nervous system. FEBS Lett 1979; 106: 305-308.

14. Mintz BL. Genetic mosaicism and in vitro analysis of neoplasia and differentiation. In: Saunder GF, ed. Cell Differentiation and Neoplasia. New York: Raven Press, 1978: 27-42.

15. Hay ED. Extracellular matrix. J Cell Biol 1981; 91 : 205-223.

16. Kramer RH, Vogel KG, Nicolson GL. Solubilization and degradation of subendothelial matrix glycoproteins and proteoglycans by metastatic tumor cells. J Biol Chem 1982; 257: 2678-2686.

17. Turley EA. Proteoglycans and cell adhesion: Their putative role during tumorigenesis. Cancer Metastasis Rev 1984; 3: 325-339.

18. Woods A, Hook M, Kjellen L. Relationship of heparin sulfate proteoglycan to the cytoskeleton and extracellular matrix of cultured fibroblasts. J Cell Biol 1984; 99: 1743-1753.

19. Bellon $G$, Caulet $T$, Cam $Y$ et al Immunohistochemical localization of macromolecules of the basement membrane and extracellular matrix of human gliomas and meningiomas. Acta Neuropathol 1985; 66: 245-252.
20. Giordana MT, Giaccone G, Mauro A et al. The distribution of laminin in human brain tumors: An immunohistochemical study. Acta Neuropathol 1985; 67: 51-57.

21. Kochi N, Tani E, Morimura T et al. Immunohistochemical study of fibronectin in human glioma and meningioma. Acta Neuropathol 1983; 59: 119-126.

22. Paetau A, Mellstrom K, Vaheri A et al. Distribution of a major connective tissue protein, fibronectin, in normal and neoplastic human nervous tissue. Acta Neuropathol 1980; 51: 47-51.

23. Schiffer D, Giordana MT, Migheli A. GFAP, FVIII/RAg, laminin and fibronectin in gliosarcomas: An immunohistochemical study. Acta Neuropathol 1984; 63: 108-116.

24. McComb RD, Bigner DD. Immunolocalization of monoclonal antibody-defined extracellular matrix antigens in human brain tumours. J Neuro Oncol 1985; 3: 181-186.

25. Ekblom $\mathrm{P}$, Miettinen M, Rapola J et al. Demonstration of laminin, a basement membrane glycoprotein, in routinely processed formalin-fixed human tissues. Histochemistry 1982; 75: 301-307.

26. Holund B, Clause PP, Clemmensen I. The influence of fixation and tissue preparation on the immunohistochemical demonstration of fibronectin in human tissue. Histochemistry 1981; 72: 291-299.

27. Sabatini DS, Bensch K, Barnett RJ. Cytochemistry and electron microscopy: The preservation of cellular ultrastructure and enzymatic activity by aldehyde fixation. J Cell Biol 1963; 17: 19-58.

28. Rutka JT, Giblin JR, Hoifodt $\mathrm{HK}$ et al. Establishment and characterization of a cell line from a human gliosarcoma. Cancer Res 1986; 46: 5893-5902.

29. Schachner M, Schoomaker G, Hynes RO. Cellular and subcellular localization of LETS protein in the nervous system. Brain Res 1978; 158: 149-155.

30. Chronwall BM, McKeever PE, Kornblith PL. Glial and nonglial neoplasms evaluated on frozen section by double immunofluorescence for fibronectin and GFAP. Acta Neuropathol 1983;59: 283-287.

31. Timpl R. Antibodies to collagens and procollagens. In: Cunningham LW, Frederiksen DW, eds. Methods in Enzymology. Structural and Contractile Proteins. Part A - Extracellular Matrix. New York: Academic Press, 1982; Vol. 82: 472-498.

32. Jones PA, DeClerk YA. Destruction of extracellular matrixes containing glycoproteins, elastin and collagen by metastatic human tumor cells. Cancer Res 1980; 40: 3222-3227.

33. Fidler IF, Gersten DM, Hart IR. The biology of cancer invasion and metastasis. Adv Cancer Res 1978; 28: 149-250.

34. Liotta LA, Tryggvason $\mathrm{K}$, Garbisa $\mathrm{S}$ et al. Metastatic potential correlates with enzymatic degradation of basement membrane collagen. Nature 1980; 284: 67-68.

35. Smith DR, Hardman JM, Earle KM. Metastasizing neuroectodermal tumors of the central nervous system. J Neurosurg 1969; 31: $50-58$.

36. Schuster H, Jellinger K, Gund A et al. Extracranial metastases of anaplastic cerebral gliomas. Acta Neurochir (Wien) 1976; 35: 247-259.

37. Cerame MA, Guthikonda M, Kohli CM. Extraneural metastases in gliosarcoma: A case report and review of the literature. Neurosurgery $1985 ; 17: 413-419$.

38. Jellinger K. Glioblastoma multiforme: Morphology and biology. Acta Neurochir 1978; 42: 5-32.

39. Liesi $\mathrm{P}$, Dahl D, Vaheri A. Laminin is produced by early rat astrocytes in primary culture. J Cell Biol 1983; 96: 920-924. 